Vol. 1, No. 1, March 2019 e-ISSN: 2656-4882 p-ISSN: 2656-5935

http://journal-isi.org/index.php/isi

Published By DRPM-UBD

\title{
Palembang Explore Application Using Android
}

\section{Aplikasi Palembang Explore Menggunakan Android}

\author{
Nyimas Sopiah ${ }^{1}$, Redho Aidil Iqrom ${ }^{2}$ \\ 1,2Informatics Department, Bina Darma University, Palembang, Indonesia \\ Email: ${ }^{1}$ nyimas.sopiah@binadarma.ac.id, ${ }^{2}$ r.a.irrom@student.binadarma.ac.id
}

\begin{abstract}
Palembang city is one of the big cities in Indonesia. There are many attractions that can be seen and promoted in this city. Various types of tourism objects that can be developed. Some that can be seen are historical places, places to buy souvenirs and snacks. These three objects are a number of objects that are usually an attraction for people who will visit this city. This software will be created as a mobile application that will be designed and built with extreme programming method which includes the stages of planning, design, coding and testing. The tools in designing are using the Unified Modeling Language (UML) by making use case diagrams and class diagrams. The Palembang Explore software (application) using the Android operating system is expected to be used by everyone who needs information about attractions, souvenirs and culinary purchases in the city of Palembang and can be a medium to introduce the city of Palembang more specifically to the wider community so that it can helped promote the city of Palembang in South Sumatra as one of the promotional assets owned by the Indonesian Nation.
\end{abstract}

Keywords: Palembang Explore, Extreme Programming, Android.

\section{PENDAHULUAN}

Era zaman sekarang Teknologi Informasi semakin maju dan berkembang pesat, tidak menutup kemungkinan pula untuk bersosialisai dan sistem bisnispun semakin maju. Beberapa kemajuan Teknologi yangmemunculkan berbagai jenis kegiatan yang berbasis pada teknologi informasi, seperti e-commerce, e-education, egovernment dan lain-nya. Dan sepertinya tidak dapat dipungkiri masih banyak lagi hal lain yang memerlukan Teknologi Informasi seperti informasi untuk mengetahui suatu tempat atau spot, toko oleh-oleh (suvenir), dan makanan khas daerah yang ada di daerah ketika sedang berlibur. Dilihat dari perkembangnya, Kota Palembang merupakan salah satu kota yang ada di Indonesia yang memiliki banyak kegiatan, baik nasional maupun internasional. Ada beberapa event (kegiatan) bertaraf Asia yang sudah diselenggarakan di Kota Palembang, antara lain Sea Games. Banyak wisatawan nasional dan asing yang datang ke Indonesia tepatnya di 
Kota Palembang. Semakin banyak wisatawan yang datang di Kota Palembang maka semakin banyak pula tempat-tempat wisata yang ada di Kota Palembang banyak di kunjungi.

Kota Palembang sendiri salah satu kota besar yang ada di Indonesia, kota ini terkenal dengan hasil kerajinan khas kota Palembang dan makanan khas daerah nya. Di Kota Palembang tidak hanya terkenal dengan makanan dan kerajinan nya tetapi terkenal juga dengan tempat wisata yang banyak dicari oleh wisatawan. Dari fakta yang ada di atas dengan banyaknya jumlah wisatawan yang ada dan ingin berkunjung, ada pula wisatawan yang ingin berkunjung tetapi tidak mengetahui tempat-tempat wisata, toko oleh-oleh (suvenir), dan makanan khas daerah yang ada di Palembang, ini sungguh menjadi masalah kecil yang harus diatasi untuk menyambut Event Asia yang sebentar lagi di selenggarakan. Berdasarkan permasalahan yang ada maka dibuatlah aplikasi Aplikasi Palembang Explore Menggunakan Android.

Penelitian yang menggunakan sistem operasi Android adalah penelitian yang dihasilkan oleh Usman Ependi dan Nyimas Sopiah (2015). Penelitian ini menghasilkan sebuah aplikasi pembelajaran Matematika berbasis Android yang digunakan oleh siswa kelas enam Sekolah Dasar [1]. Pitrawati dan Mega Wati Ayu Ningsih melakukan penelitian dengan membuat perangkat lunak untuk mencari lokasi wisata di Lampung. Penelitian ini juga merupakan penelitian yang menggunakan metode extreme programming dan tools yang dipakai menggunakan Unified Modelling Language (UML) [2]. Berikutnya adalah penelitian dari I Gusti Ngurah Jelantik Suryaningrat yang menghasilkan sebuah perangkat lunak untuk mencari kuliner. Informasi yang dihasilkan dari penelitian ini adalah informasi tentang jenis-jenis makanan yang ada di suatu daerah dan lokasi kuliner tersebut berada. Perangkat lunaknya menggunakan Ajax dan Code Igniter [3]. Penelitian berikutnya berjudul Aplikasi Wisata Berplatform Android dengan Teknologi QR Code. Penelitian ini menghasilkan sebuah aplikasi untuk mempromosikan tempat wisata Kebun Binatang Ragunan. Tujuan dari penelitian ini adalah menghasilkan aplikasi berbasis mobile device berbasis Android yang menghasilkan informasi secara online dan dapat melihat lokasi melalui peta digital. Untuk melihat peta dari sebuah lokasi tersebut, maka peneliti menggunakan scan QR code [4].

Penelitian yang berjudul "Kencolepot Aplikasi Pencarian Tempat Wisata di Bandung" menghasilkan penelitian yang mencari lokasi tempat wisata di daerah Bandung. Kencolepot merupakan adalah aplikasi mobile untuk membantu wisatawan, warga Bandung, ataupun pelajar yang sedang menuntut ilmu di Bandung jika mereka ingin mencari tempat wisata kuliner yang sesuai dengan budget uang saku mereka. Aplikasi yang dihasilkan menggunakan sistem operasi Android [5]. 


\section{METODOLOGI PENELITIAN}

Ada beberapa metode yang digunakan dalam penelitian ini. Berikut uraian dari metode-metode yang dipakai.

\subsection{Objek Penelitian}

Objek dari penelitian ini adalah tempat wisata, tempat suvenir dan tempat kuliner yang ada di Kota Palembang.

\subsection{Metode Pengumpulan Data}

Metode pengumpulan data yang digunakan dalam penelitian ini terdiri dari beberapa bagian, yaitu:

1) Wawancara

Penelitian ini mengumpulkan data dengan mengadakan wawancara kepada beberapa tempat wisata, pemilik penjualan oleh-oleh atau suvenir, pemilik penjualan kain khas Palembang, pemilik penjualan kuliner yang ada di Kota Palembang. Wawancara dilakukan untuk meminta izin tempatnya untuk didokumentasikan dan bertanya mengenai tempatnya masing-masing.

2) Pengamatan

Pengamatan dilakukan dengan mengamati objek-objek wisata yang terdiri dari beberapa tempat wisata, pemilik penjualan oleh-oleh atau suvenir, pemilik penjualan kain khas Palembang, pemilik penjualan kuliner yang ada di Kota Palembang.

3) Studi Literatur

Studi literatur merupakan salah satu bagian yang digunakan untuk mendapatkan informasi yang berkaitan dengan penelitian ini. Studi dilakukan mulai dari pengumpulan data-data wisata, suvenir dan kuliner Kota Palembang serta data-data referensi penelitian.

\subsection{Metode Pengembangan Aplikasi / Perangkat Lunak}

Metode pengembangan aplikasi atau perangkat lunak yang digunakan dalam penelitian ini adalah Extreme Programming. Extreme Programming (XP) merupakan metode pengembangan perangkat lunak yang di dalam proses pengembanganya dibuat sederhana sehingga proses tersebut menjadi lebih adaktif dan fleksibel. XP termasuk dalam pengembangan perangkat lunak yang iteratif [6]. Adapun tahapan dari metode ini adalah: 
1) Planning (Perencanaan)

Pada tahap ini yang dilakukan adalah dengan mengumpulkan data awal, dimulai dari pengumpulan foto dan identitas dari objek wisata, kuliner dan makanan khas Palembang.

2) Design (Rancangan)

Tahap ini dengan melakukan rancangan aplikasi. Rancangan yang dihasilkan menjadi sebuah bentuk dari aplikasi yang dibuat. Rancangan dalam penelitian ini menggunakan alat bantu (tools) skenario, use case diagram dan class diagram.

3) Coding (Pengkodean)

Tahap ini merupakan tahap pembuatan perangkat lunak.

4) Testing (Pengujian)

Tahap ini merupakan pengujian terhadap perangkat lunak atau aplikasi yang telah dihasilkan.

\subsection{Android}

Android merupakan sistem operasi yang sangat poluper di seluruh dunia. Penggunaan Android sudah lebih dari 190 negara di seluruh dunia. Banyak pengguna menggunakan sistem operasi $A$ droid untuk mencari aplikasi, permainan dan konten digital lainnya. Android menjadi sistem operasi mobile yang tumbuh paling cepat. Setiap hari lebih dari 1 juta perangkat Android diaktifkan di seluruh dunia [7].

\subsection{Unified Modelling Language}

Whitten \& Bentley mengemukakan bahwa Unified Modeling Language (UML) merupakan kumpulan dari model yang digunakan untuk menjelaskan sistem dari perangkat lunak sebagai objek [8].

\section{HASIL DAN PEMBAHASAN}

\subsection{Perencanaan}

Tahap ini meruppaka tahap untuk mendapatkan informasi bahwa di Kota Palembang memiliki beragam tempat objek wisata yang menarik dan juga tempat penjualan (market store) oleh-oleh Kota Palembang. Dari berbagai macam wisata yang ada di Palembang itu ada beberapa objek wisata yang dibilang masih baru atau lagi trend pada saat ini. 


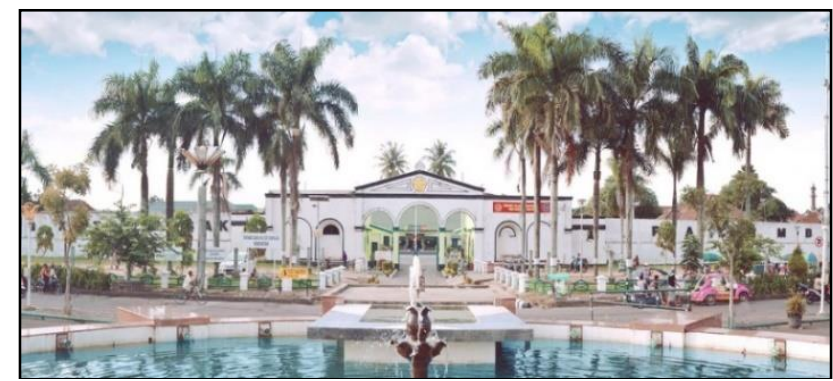

Gambar 1. Benteng Kuto Besak

Bicara tentang objek wisata yang ada di Kota Palembang yang ada saat ini memang tidak ada habis nya, salah satunya objek yang paling lama ada di Kota Palembang yaitu Benteng Kuto Besak (BKB) dan Jembatan Ampera yang merupakan salah satu icon Kota Palembang dimana dari dulu hingga saat ini masih menarik untuk wisatawan yang datang. Bagi wisatawan yang datang dari luar daerah Kota Palembang pasti objek yang akan dituju pertama kali yaitu Jembatan Ampera dan Benteng Kuto Besak (BKB) karena bukan hanya menjadi salah satu icon di Kota Palembang objek wisata ini ada hal menarik lain nya yaitu dimana-mana kebanyakan objek wisata bagi pengunjung itu ada tarif nya tapi jika di JembatanAmpera dan Benteng Kuto Besak (BKB) ini tidak dipungut biaya hanya saja jika ada pengunjung yang datang membawa kendaraan itu hanya di kenakan biaya parker kendaraan saja, selain itu objek wisata ini sangat ramai di kunjungi dari kaum muda hingga tua.

Selain objek wisata yang di atas masih banyak objek wisata yang ada di kota Palembang ini, trerlepas dari itu kota Palembang juga memiliki hasil karya kerajinan tangan yaitu Kain Songket yang merupakan ciri khas dari kota Palembang, berdasarkan informasi yang ada saat ini salah satu tempat penjualan songket yang terkenel di kota Palembang yaitu Zainal Songket. Dan informasi lainnya yaitu Kain Songket biasa di pakai pada saat acara-acara resmi dan pembuatan nya membutuhkan waktu hingga 3 bulan.

Terlepas dari objek wisata dan hasil kerjajinan tangan khas kota pale,bang sekarang kita beralih ke makana khas daerah Kota Palembang yaitu Pempek (Empek-Empek) menurut informasi yang di dapat makan khas kota Palembang ini mempunyai sejarah unik dikarenakan kata pempek itu berasal dari kebiasaan masyarakat yang memanggil penjual pempek, konon katanya pada saat itu sudah ada sejak masyarakat tionghoa masuk ke Kota Palembang dan penjual pempek pada saat itu rata-rata masyarakat tionghoa yang menjajakan pempek dan rata-rata anak muda sering memanggil penjual dengan sebutan "Pek, empek, mampir sini". 
Vol. 1, No. 1, March 2019

p-ISSN: 2656-5935 http://journal-isi.org/index.php/isi e-ISSN: 2656-4882

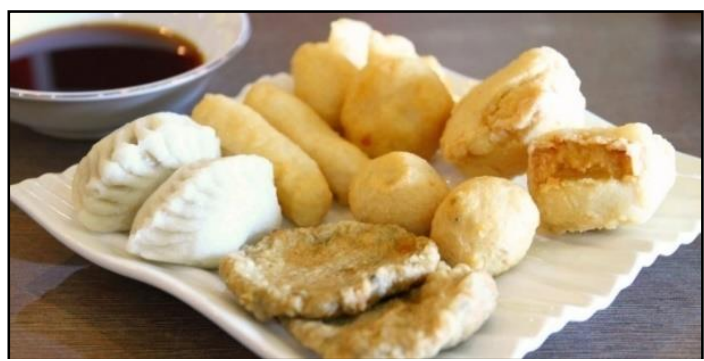

Gambar 2. Makanan Khas Kota Palembang (Pempek)

Dan pempek juga merupakan salah satu makan yang cocok dihidangkan kapan saja termasuk juga acara-acara resmi. Jika dulu penjual pempek masih dengan cara di jajakan berbeda dengan sekarang yang sudah menjadi makanan khas daerah pempek kini sangat mudah kita jumpai di toko-toko besar dan pempek juga ada berbagai macam nama-nya dan bentuk-nya maka dari itu beragam pula harga yang di pasarkan, tetapi hingga saat ini masih ada penjual yang memasarkan pempek dengan cara di jajakan seperti dulu.

\subsection{Perancangan}

Rancangan yang digunakan dalam penelitian ini terdapat beberapa di antaranya adalah pertama membuat skenario. Skenario yang dihasilkan terdiri dari kelola logi, kelola halaman utama, kelola kategori, kelola data wisata, kelola suvenir, pilih objek wisata, dan pilih suvenir. Rancangan kedua adalah dengan membuat use case diagram. Use case diagram yang dihasilkan berdasarkan skenario. Pada rancangan ini kelihatan aktornya dan apa yang dilakukan aktor di dalam menggunakan aplikasi.

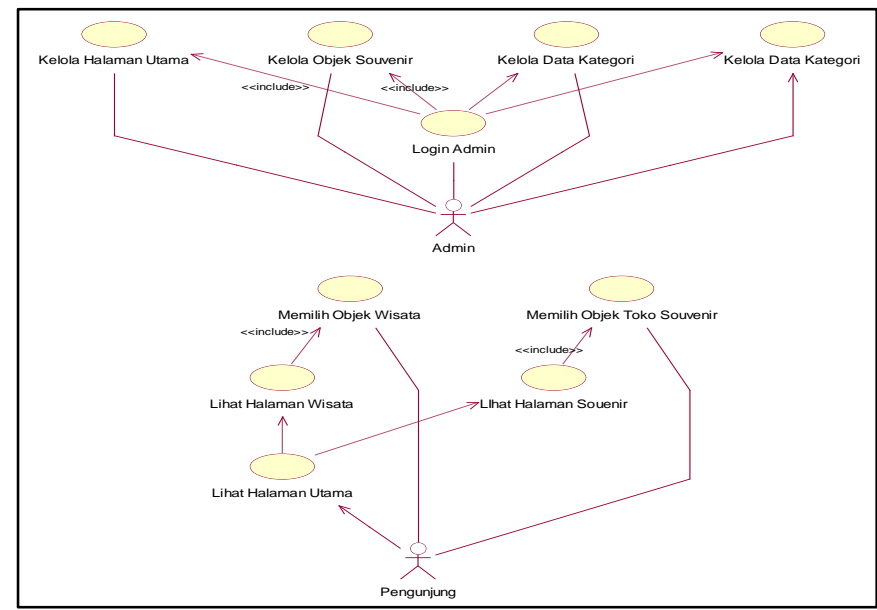

Gambar 3. Use Case Diagram 
Rancangan ketiga adalah dengan membuat Class Diagram. Class diagram dihasilkan berdasarkan skenario. Dimana dari penguraian skenario, maka diuraikan lebih detail menjadi kelas-kelas dari objek yang ada. Berikut class diagram dari aplikasi ini.

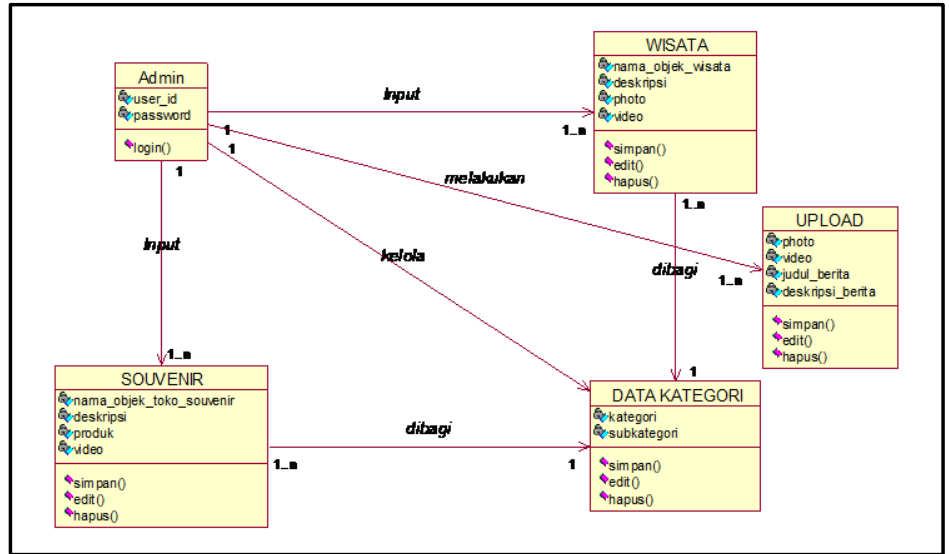

Gambar 4. Class Diagram

\subsection{Pengkodean}

Pada tahap ini, pengkodean yang digunakan adalah menggunakan bahasa pemrogram HTML 5. Berdasarkan rancangan pada tahap sebelumnya, maka dihasilkan beberapa tampilan aplikasi. Pertama kali masuk ke aplikasi yang tampil adalah tampilan halaman utama dari Android, yaitu Home. Home merupakan tampilan utama ketika kita membuat aplikasi ini. Di dalam tampilan ini akan memilih beberapa pilihan objek yang akan kita lihat.

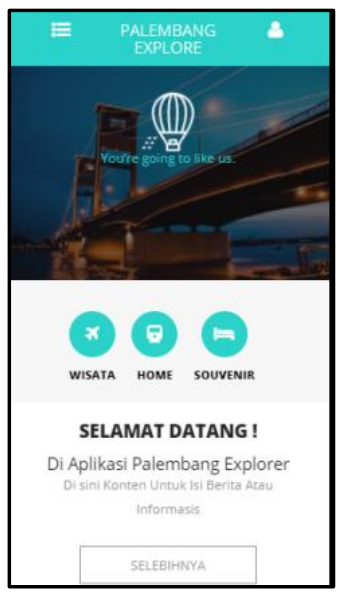

Gambar 5. Tampilan Home 
Vol. 1, No. 1, March 2019

p-ISSN: 2656-5935 http://journal-isi.org/index.php/isi

e-ISSN: 2656-4882

Tampilan berikutnya adalah menampilkan halaman tujuan atau objek yang akan kita lihat. Ada tiga objek yang akan tampilan. Pertama adalah objek wisata. Objek wisata di sini merupakan objek-objek yang ada di Kota Palembang, berikut contoh dari tampilan objek wisata.

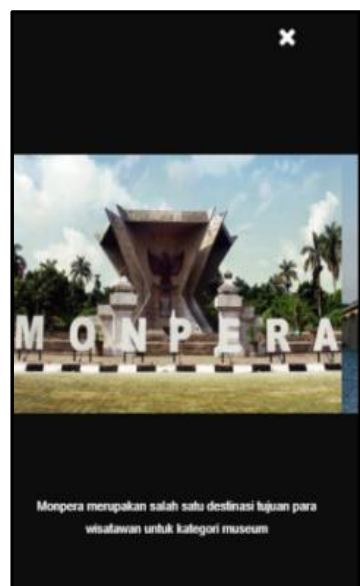

Gambar 6. Tampilan Objek Wisata

Tampilan berikutnya adalah tampilan objek suvenir. Halaman ini akan menampilkan tempat-tempat pembelian suvenir oleh wisatawan yang akan berkunjung. Berikut contoh tampilan dari objek suvenir.

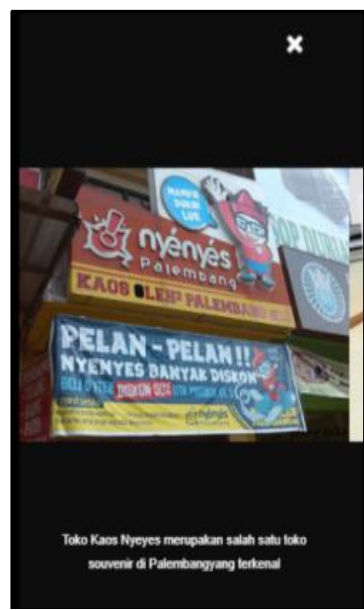

Gambar 7. Tampilan Objek Suvenir

Tampilan berikutnya dalah tampilan objek kuliner. Berikut gambar dari tampilan tersebut. 


p-ISSN: 2656-5935 http://journal-isi.org/index.php/isi e-ISSN: 2656-4882

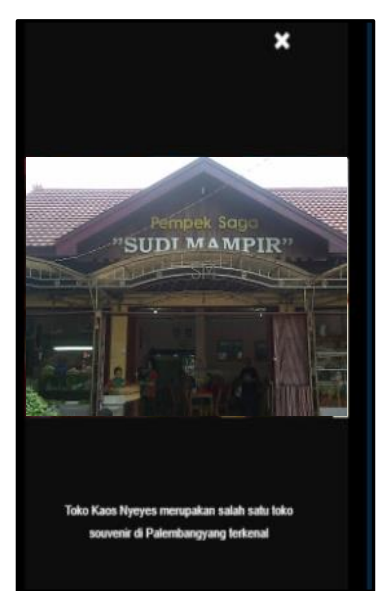

Gambar 8. Tampilan Objek Kuliner

\subsection{Pengujian}

Tahap ini adalah tahap pengujian aplikasi Palembang Explore berbasis Android sebagai upaya untuk mempromosikan Kota Palembang. Pengujian telah dilakukan secara menyeluruh mulai dari basis data yang digunakan sampai dengan aplikasi Palembang Explore baik yang berbasis web sebagai sistem yang memanajemen perangkat lunak maupun perangkat lunak yang berjalan di aplikasi mobile yang akan digunakan oleh pengguna (user). Setelah dilakukan pengujian, dapat dikatakan bahwa aplikasi telah berjalan dengan baik dan lancar.

\section{SIMPULAN}

Setelah pembahasan telah diuraian sebelumnya, maka telah dihasilkan sebuah aplikasi explore Kota Palembang yang terdiri dari pencarian objek wisata, objek suvenir dan objek kuliner. Aplikasi ini diharapkan dapat membantu wisatawan yang akan berkunjung ke Kota Palembang. Sehingga promosi mengenai Kota ini dapat dilakukan dengan baik.

\section{REFERENSI}

[1] U. Ependi and N. Sopiah, "Aplikasi Media Belajar Matematika Berbasis Android," in Seminar Nasional Teknologi Informasi (SNTI), 31 Oktober 2015, Jakarta, 2015. 
[2] Pitrawati and M. W. Ayu Ningsih, "Rekayasa Perangkat Lunak pada Informasi Pemetaan Lokasi Wisata Lampung," vol. 14, no. 2, 2017.

[3] I. G. Ngurah Jelantik Suryaningrat, "Perancangan Sistem Informasi Wisata Kuliner Berbasis Web dengan menggunakan Ajax dan Code Igniter," vol. 10, no. 2, 2016.

[4] A. Galih Sarman, "Aplikasi Wisata Berflatform Android dengan Teknologi QR Code," Jurnal Comtech, p-ISSN:2087-1244, e-ISSN:2476-907X, pp. 719730, 2013.

[5] H. A. Mawadah, "Kencelepot Aplikasi Pencarian Tempat Wisata Kuliner di Bandung Berbasis Android," Bandung, 2015.

[6] S. Cesarya, "Agile Development VS Extreme Programming," 20 Januari 2018. [Online]. Available: https://www.academia.edu/7558840/Agile_De velopment_VS_Extreme_Programming. [Accessed 12 Juni 2018].

[7] A. Developer, "Android, the World's Most Popular Mobile Platform," p. 1, 24 May 2014.

[8] L. D. Bentley and J. L. Whitten, Systems. Analysis and Design for the Global Enterprise Seventh Edition, New York: McGraw-Hill, 2007. 